HNF-2782-FP

UC-2030

\title{
Reverse Polarity Capillary Zone Electrophoresis Analysis of Nitrate and Nitrite in Natural Water Samples
}

S. G. Metcalf

Numatec Hanford Corporation

Date Published

May 1998

To Be Published in

Journal of Analytical Chemistry

Prepared for the U.S. Department of Energy

Assistant Secretary for Environmental Management

Fluor Daniel Hanford, Inc.

P.O. Box 1000

Ricliland. Washington

Hanford Manegentent and Integration Contracior for the

U.S. Department of Energy under Contraet DE-AC06-96RL13200

Copyriaht Licens By scceptance of this artida, the pubtisher and/or rocipient acknowledges the

U.S. Government's right eo retein a nonexctugive, royslty-free licerese in and to any copyright covering thic poper.

Approved for Public Release; Further Dissemination Unlimited 


\section{INFORMATION CLEARANCE FORM}

\begin{tabular}{|ll}
\hline \multicolumn{2}{|c}{ A. Information Category } \\
$\square$ Abstract & $\square$ Journal Article \\
$\square$ Summary & $\square$ Internet \\
$\square$ Visual Aid & $\square$ Software \\
$\square$ Full Paper & $\square$ Report \\
$\square$ Other & \\
\hline
\end{tabular}
B. Document Number HNF-2782-FP
C. Title
Reverse Polarity Capillary Zone Electrophoresis Analysis of
Nitrate and Nitrite in Natural Water Samples
D. Internet Address steven g metcalfarl.gov

E. Required Information

1. Is document potentially Classified? $[\mathrm{X}]$ No $\square$ Yes (MANDATORY)

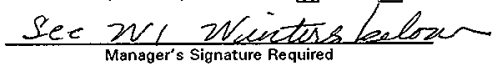

If Yes $[$ No $\square$ Yes Classified ADC Signature Required

$[\mathrm{X}]$ No $\square$ Yes

2. Internal Review Required?

If Yes, Document Signatures Below

Counsel

Program

3. References in the Information are Applied Technology

Export Controlled Information

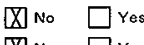

4. Does Information Contain the Following: (MANDATORY)

a. New or Novel (Patentabie) Subject Matter? $\quad[X]$ No $\square$ Yes

If "Yes", Disclosure No.

b. Information Received in Confidence, Such as Proprietary and/or Inventions?

$\mathbb{X}$ No $\square$ Yes if "Yes", Affix Appropriate Legends/Notices.

c. Copyrights? $[\mathbb{X}$ No $\square$ Yes if "Yes", Attach Permission.

d. Trademarks? $\square$ No $\square$ Yes if "Yes", Identify in Document.

5. Is Information requiring submission to OSTI? $\square$ No $[\mathrm{X}$ Yes

If Yes $U C-\frac{2}{2} 030$ and $B \& R-E W 3120072$

6. Release Level? $\mathrm{X}$ Public $\square$ Limited HANAO700

$[$ No $\square$ Yes 7. charge code N2EBA KA 4 lo44 Live ter 7

F. Complete for a Journal Article

1. Title of Journal Analytical Chemistry

G. Complete for a Presentation

1. Title for Conference or Meeting

2. Group Sponsoring

3. Date of Conference

5. Will Information be Published in Proceedings? $\square$ No $\square$ Yes

4. City/State

H. Author/Requestor

6. Will Material be Handed Out? $\square$ No $\square$ Yos

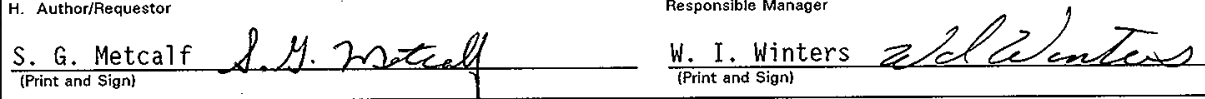

\begin{tabular}{ll}
\hline I. Reviewers Yes Print \\
\hline
\end{tabular}

Signature

Public $\mathrm{Y} / \mathrm{N}$ (If $\mathrm{N}$, complete $\mathrm{J}$

General Counsel

$\triangle$ Barbax D. Williamson

Office of External Affairs

S.A. Woody

DOE-RL

$\triangle$ D.H. Irby

Other

Other

$\square$
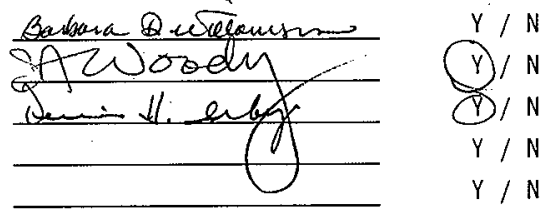

J. If Information Includes Sensitive Information and is not to be released to the Public indicate category below.

$\square$ Applied Technology $\square$ Protected CRADA

$\square$ Personal/Private $\square$ Export Controlled

$\square$ Proprietary $\square$ Procurement-Sensitive

$\square$ Business-Sensitive $\square$ Patentable

$\square$ Predecisional

$\square$ Other (Specify)

$\square$ UCNi

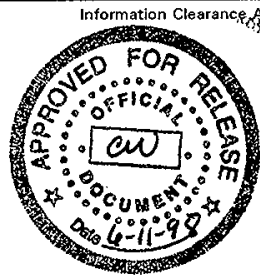




\title{
RELEASE AUTHORIZATION
}

Document

Number:

HNF-2782-FP

Document

Title:
Reverse Polarity Capillary Zone Electrophoresis Analysis of Nitrate and Nitrite in Natural Water Samples

\section{This document, reviewed in accordance with DOE Order 1430.1D, "Scientific and Technical Information Management," and DOE G 1430.1D-1, "Guide to the Management of Scientific and Technical Information," does not contain classified or sensitive unclassified information and is:}

\section{APPROVED FOR PUBLIC RELEASE}

\author{
Chio

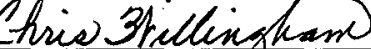 \\ Christine witlingham \\ Lockheed Martin Services, Inc. \\ Document Control/Information Clearance
}

$6 / 11 / 98$

Reviewed for Applied Technology, Business Sensitive, Classified, Copyrighted, Export Controlted, Patent, Personal/Private, Proprietary, Protected CRADA, Irademark, Unclassified Controlled Nuclear Information.

LEGAL DISCLAIMER. This report was prepared as an account of work sponsored by an agency of the United States Government. Neither the United States Government nor any agency thereof, not any of their employees, nor any of their contractors, subcontractors or their employees, makes any warranty, express or implied, or assumes any legal liability or responsibility for the accuracy, completeness, or any third party's use or the results of such use of any information, apparatus, praduct, or process disclosed, or represents that its use would not infringe privately owned rights. Reference herein to any specific commercial product, process, or service by trade name, trademark, manufacturer, or otherwise, does not necessarily constitute or imply its endorsement, recommendation, or favoring by the United states Government or any agency thereof or its contractors or subcontractors. The views and opinions of authors expressed herein do not necessarily state or reflect those of the United States Government or any agency thereof. This report has been reproduced from the best available copy. Printed in the United States of America. Available to the U.S. Department of Energy and its contractors from the U.S. Department of Energy Office of Scientific and Technical Information, P.0. Box 62, Oak Ridge, TH 37831; Telephone: 423/576-8401.

Available to the public from the U.S. Department of Comerce National Technical Infornation Service, 5285 Port Royal Road, Springfield, VA 22161; Telephone: 703/487-4650. 
REVERSE POLARITY CAPILLARY ZONE ELECTROPHORETIC ANALYSIS OF NITRATE AND NITRITE IN NATURAL WATER SAMPLES

\author{
ASOPURU A. OKEMGBO ${ }^{\text {a }}$, WILLIAM F. SIEMS, \\ AND HERBERT H. HILL*. \\ DEPARTMENT OF CHEMISTRY \\ WASHINGTON STATE UNIVERSITY \\ PULLMAN, WA 99164-4630.
}

and

STEVEN G. METCALF

NUMATEC HANFORD COMPANY

P. O. BOX 1300, RICHLAND, WA 99352

\title{
SUBMITED TO ANALYTICAL CHEMISTRY \\ MARCH 1998
}

$a=$ Current Address: Washington State University Tri-Cities, 2710 University Drive, Richland, WA 99352

* = Author to whom correspondence should be addressed. (E-mail: hhhill@wsu.edu or FAX: 509-335-8867) 


\section{ABSTRACT:}

This paper describes the application of reverse polarity capillary zone electrophoresis (RPCE) for rapid and accurate determination of nitrate and nitrite in natural water samples. Using hexamethonium bromide (HMB) as an electroosmotic flow modifier in a borate buffer at $\mathrm{pH} 9.2$, the resolution of nitrate and nitrite was accomplished in less than 3 minutes. RPCE was compared with ion chromatographic (IC) and cadmium reduction flow injection analysis (CdFIA) methods which are the two most commonly used standard methods for the analysis of natural water samples for nitrate and nitrite. When compared with the ion chromatographic method for the determination of nitrate and nitrite, RPCE reduced analysis time, decreased detection limits by a factor of 10 , cut laboratory wastes by more than two orders of magnitude, and eliminated interferences conmonly associated with IC. When compared with the cadmium reduction method, RPCE had the advantage of simultaneous determination of nitrate and nitrite, could be used in the presence of various metallic ions that normally interfere in cadmium reduction, and decreased detection limits by a factor of 10 .

\section{INTRODUCTION:}

Many methods have been used for the determination of nitrate and nitrite in natural water samples. Most important are spectrophotometric, cadmium reduction, and ion chromatographic methods. Spectrophotometric methods often involve direct measurement of nitrate and nitrite absorption at wavelengths of $210 \mathrm{~nm}, 302 \mathrm{~nm}$, and $355 \mathrm{~nm}^{1,2}$. Reduction of nitrate to nitrite, and further conversion into an azo dye coupled with aromatic amines has also been used ${ }^{3}$. Colorimetric methods, however, are plagued with many interferences such as dissolved organic 
matter and chromium (VI). Another disadvantage of the azo derivatization of nitrite is that precipitation can occur under test conditions when $\mathrm{Sb}^{3+}, \mathrm{Au}^{3+}, \mathrm{Bi}^{3+}, \mathrm{Fe}^{3+}, \mathrm{Pb}^{2+}, \mathrm{Hg}^{2+}$, and $\mathrm{Ag}^{+}$ ions are present in a sample. The presence of $\mathrm{Cu}^{2+}$ ion may catalyze the decomposition of the diazonium salt, and hence cause low results.

Cadmium reduction flow injection analysis (Cd-FIA) and ion chromatographic methods are the commonly used standard methods for the examination of seawater and wastewater ${ }^{4-6}$. When operating under optimum conditions, the cadmium reduction method has a detection limit of 10 $\mathrm{ppb}-\mathrm{N}$ for both nitrate and nitrite, with a common analytical operating range of $10 \mathrm{ppb}$ to $1 \mathrm{ppm}$. Although the cadmium reduction method has been automated and can analyze samples every $2-3$ minutes, the column washing and preconditioning procedures are still tedious and time consuming. Like the spectrophotometric methods, the cadmium reduction method is matrix sensitive. It may not be used for samples containing high levels of copper, iron and other metallic ions in solution which lower the efficiency of the reduction process. A primary disadvantage of cadmium reduction is that the volume of hazardous waste generated is high and the cadmium in the solvent waste must be eliminated before waste discharge. For analyses requiring the determination of nitrate as well as nitrite, the sample has to first be analyzed for nitrite omitting the reduction step, and then repeated for nitrate via the reduction.

Ion chromatography is the method recommended by the US- EPA for nitrate and nitrite ${ }^{7}$. The analysis time for suppressed conductivity detection of nitrate and nitrite is less than 5 minutes, with detection limits of $20 \mathrm{ppb}-\mathrm{N}$ and $40 \mathrm{ppb}-\mathrm{N}$ for nitrate and nitrite respectively. The analytical operating range for nitrate and nitrite are 0.42 to $14.0 \mathrm{ppm}-\mathrm{N}$ and 0.36 to $12.0 \mathrm{ppm}-\mathrm{N}^{7}$ 
respectively. For samples containing high chloride concentrations like seawater, the chloride ion interferes with nitrite ${ }^{8}$. Moreover, the oxidation of nitrite to nitrate occurs under the acidic conditions of the suppressor column ${ }^{9}$. As with the cadmium reduction method, the IC method also generates high volumes of wastes.

In today's environmental analytical applications, there is a critical need to find and demonstrate technologies that will result in waste minimization and waste avoidance while significantly reducing overall costs. In this study, reverse polarity capillary zone electrophoresis was investigated as an analytical method for nitrate and nitrite that would be suitable for the rapid monitoring of natural waters and aquifers.

Several investigators have reported the use of capillary zone electrophoresis (CZE) with direct ${ }^{10-}$ ${ }^{14}$ and indirect ${ }^{15-21} \mathrm{UV}$, and suppressed conductivity ${ }^{21}$ detection for the analysis of nitrate and nitrite in aqueous and other samples. Amran and co-workers ${ }^{12}$ optimized the analysis of anions by direct detection at $200 \mathrm{~nm}$, in a pH 3 phosphate buffer, separating nitrate ions in about 4 minutes. They also observed that the presence of chloride interfered with the quantification of nitrate peak for samples with high chloride content.

Romano et al ${ }^{15}$ and Jones and Jandik ${ }^{16-17}$ used an indirect detection method at $254 \mathrm{~nm}$, with Nice-Pak OFM Anion BT electroosmotic flow modifier and sodium chromate as electrolyte at pH 8.0 for the separation of anions. The modifier added to the electrolyte caused the electroosmotic flow to move in the same direction as that of the anions, under negative voltage polarity configuration. Poor peak shapes were observed for fluoride and phosphate due to the 
mismatch of the electrolyte mobility with the mobilities of these ions. The investigators showed that the electroosmotic modifier ion-paired with bromide, nitrate, and sulfate, and hence led to a decrease in their mobilities, with increase in the osmotic flow modifier (OFM). $\mathrm{Li}$ and $\mathrm{Li}^{18}$ also used chromate buffer as indirect UV background for the detection of nitrate and nitrite with cetyltrimethylammonium bromide (CTAB) as electroosmotic flow modifier to reduce and reverse the electroosmotic flow. The major disadvantages of this indirect detection method are the high detection limit and narrow dynamic range of only $2-50 \mathrm{ppm}^{17}$.

Kelly and Nelson ${ }^{19}$ used 1,2,4,5 benzene tetracarboxylic acid (pyromellitic acid, PMA) as an absorbing background electrolyte for anions at $205 \mathrm{~nm}$. They used diethylene triamine (DETA) to slow down the electroosmotic flow at $\mathrm{pH}$ 9.6. Separation of anions was best achieved at 60 ${ }^{\circ} \mathrm{C}$, with possible co-migration of nitrate/sulfate at low temperatures, and nitrate/oxalate at $50^{\circ} \mathrm{C}$. Shamsi and Danielson ${ }^{20}$ used naphthalenesulfonate as electrolyte for indirect photometric detection of anions, organic acids and surfactants. Borate buffer with DETA as electroosmotic modifier was also used at $\mathrm{pH} 8$. The detection limit range for the anions were $80-350 \mathrm{ppb}$. For nitrate and nitrite, detection limits were 110 and $125 \mathrm{ppb}$ respectively.

Limitations associated with spectrophotometric methods, FIA, IC, and some of the CZE methods for nitrate and nitrite can be summarized as interferences by both cations and anions, high detection limits, narrow dynamic range, and poor separation efficiencies. The overall objective of this project therefore, was to develop a simple and rapid method based on reverse polarity capillary zone electrophoresis (RPCE) which can be used for routine determination of nitrate and nitrite in natural water. In the RPCE method, negative voltage polarity was applied at 
the injection position and the electroosmotic flow, which ran opposite to the direction of electrophoretic mobility of anions, was reduced by adding an electroosmotic flow modifier, hexamethonium bromide (HMB), to the buffer. The method was therefore anion specific. Cations and neutrals were not detected. The specific objectives of this project were to determine the operating conditions that would provide the best combination of low detection limits, wide dynamic range, reduced waste generation, no cation interferences, and minimized anion interferences for the direct UV detection of the nitrate and nitrite. In addition, the concentrating effects of stacking under prolonged injection times in both gravity and pressure injection methods were examined as a means to decrease detection limits. Finally, determination of nitrate in natural water samples for limnological studies of the Lower Snake River ${ }^{22}$ using cadmium reduction and ion chromatography was compared to the novel RPCE method. Nitrate level in a domestic well water was also measured with the RPCE method.

\section{EXPERIMENTAL SECTION:}

Apparatus: A Dionex Capillary Electrophoresis System (CES) I, (Dionex Corporation, Sunnyvalle, CA) was used for these studies. This instrument was equipped with positive and negative polarity $30 \mathrm{kV}$ power supplies and an on-column UV/visible absorbance detector. The CE system was interfaced to a Dionex AI-450 Laboratory Automation System with a Dionex Advanced Computer Interface (ACI) and was operated in the remote function. The AI-450 was used for data acquisition, storage, and data reduction. Ion Chromatography experiments were carried out using a Dionex IC, (Dionex Corporation, Sunnyvalle, CA) equipped with suppressed conductivity and UV detectors. A Technicon AutoAnalyzer II (Technicon Instruments Industrial 
Systems, Tarrytown, NY), with 520-nm filter, 15-mm flow cell, S-10 photo tubes, and 30 sample/hr cam was used for the cadmium reduction analysis.

Reagents and Chemicals: Sodium nitrate (Analytical Reagent, ACS Specifications) was obtained from Mallinckrodt Chemical Works, St. Louis, MO, and sodium nitrite (Baker Analyzed Reagent, ACS Specifications) was from J.T. Baker, Inc., Phillipsburg, NJ. Sodium nitrate and sodium nitrite were dried overnight at $110^{\circ} \mathrm{C}$, cooled and stored in a dessicator. Stock solutions of nitrate and nitrite containing $1000 \mathrm{mg} / \mathrm{L}$ (as nitrate-nitrogen, and nitritenitrogen) were made from the dried sample. Sodium borate was obtained from Matheson Coleman \& Bell, Norwood, OH, and hexamethonium bromide from ICN Biochemicals, Inc., Cleveland, $\mathrm{OH}$, were used to prepare the buffer. Phthalonitrile, used as the neutral marker for determining the electroosmotic flow was obtained from Chem Service, West Chester, PA. The reagent water was from an $18 \mathrm{M} \Omega$ nanopure UV ultrapure water system (Barnstead/Thermolyne, Dubuque, IA) and was used for the preparation of all standards and buffer solutions.

Procedures: General RPCE operating conditions: In the RPCE experiments, the electrolytes used in these experiments were borate buffer solutions with hexamethonium bromide (HMB) added to control the electroosmotic flow. The borate/HMB were equimolar solutions containing $2.5,5,10$, and $25 \mathrm{mM}$ borate/HMB dilution from a stock solution of $50 \mathrm{mM}$ borate $/ 50 \mathrm{mM}$ HMB. Hexamethonium bromide is acidic ( $\mathrm{pH}$ of $100 \mathrm{mM}$ solution in water was 4.62 ) and partially converts to the hydroxide form on mixing with sodium borate, which maintains the $\mathrm{pH}$ of the buffer at $\mathrm{pH} 9.3$. All solutions were filtered with $0.45 \mu \mathrm{m}$ membrane filter and degassed prior to use. The reverse polarity mode of the capillary electrophoresis system was operated at - 
$20 \mathrm{kV}$ for the $25 \mathrm{mM}$ borate/HMB buffer and up to $-30 \mathrm{kV}$ for $2.5 \mathrm{mM}$ borate/HMB buffer. A $50 \mathrm{~cm}$ long $\times 50 \mu \mathrm{m}$ i.d. (375 $\mu \mathrm{m}$ o.d.) bare fused silica capillary was used. A small window (about $5 \mathrm{~mm}$ in length) for UV detection at $220 \mathrm{~nm}$ was created on the capillary by burning off the polyimide coating at $44.9 \mathrm{~cm}$ from the injection end. When a capillary was to be used for the first time, it was flushed with $100 \mathrm{mM}$ phosphoric acid for about 3 minutes in order to remove metal oxides precipitated on the silica walls during manufacture. It was then flushed with 500 $\mathrm{mM} \mathrm{NaOH}$ for another 16 minutes in order to reactivate the inner surface of the column. Finally, it was equilibrated with the operating buffer for about 6 minutes before sample injection. Gravity injection, which has been shown to be more reproducible and exhibit less discrimination among ions than electromigration injection, was used $d^{23}$. To inject samples, the sampler head was raised to $100 \mathrm{~mm}$ above the buffer source vial for $60 \mathrm{~s}$, unless otherwise specified. Sample volume injected (in nanoliters), was determined by using the Poiseuille equation as given below ${ }^{24}$ for a buffer viscosity close to that of water at $20-22^{\circ} \mathrm{C}$.

$$
v=\frac{2.84 \times 10^{-8} h t d^{4}}{l}
$$

where $v$ is the sample volume $(\mathrm{nL})$ injected, $h$ is the head height $(\mathrm{mm})$ of the injector above the buffer source vial, $t(\mathrm{~s})$ is the injection time, $d(\mu \mathrm{m})$ is the capillary i.d., and $l(\mathrm{~cm})$ is the total capillary length. For the conditions given above, the sample injection volume was calculated to be about $20 \mathrm{~nL}$ in a column of about $1 \mu \mathrm{L}$ total volume. 
In the study of the effects of buffer concentration on sensitivity and resolution, $2.5,5,10$, and 25 $\mathrm{mM}$ borate/HMB buffer concentrations were used. Nitrate and nitrite peaks were monitored by direct UV measurement at $220 \mathrm{~nm}$. Sample concentrations were $130 \mu \mathrm{M} \mathrm{NO}_{2}^{-}$and $110 \mu \mathrm{M}$ $\mathrm{NO}_{3}^{-}$. The separation was carried out in a $50 \mathrm{~cm}$ long $x 50 \mu \mathrm{m}$ i.d. bare fused silica column, with an applied voltage of $-20 \mathrm{kV}$ at the injection end, and a gravity injection time of $60 \mathrm{~s}$ with an injector head height of $100 \mathrm{~mm}$. These conditions were used for all of the experiments unless stated otherwise.

In detection limit studies, gravity injection was carried out with injection times from 30 to 1000 seconds at an injector head height of $100 \mathrm{~mm}$. Dilute samples were prepared in reagent water rather than in dilute buffer to achieve a low buffer-to-sample conductivity ratio. Other RPCE conditions described above applied.

Reproducibility and accuracy studies in water samples to which nitrate and nitrite standards had been added were carried out in a $2.5 \mathrm{mM}$ borate $2.5 \mathrm{mM} \mathrm{HMB}$ buffer. The water samples used were reagent water, drinking water, and lab tap water. From the stock solutions, mixtures of nitrate and nitrite were prepared at concentrations of $1.0 \mathrm{ppm}, 1.68 \mathrm{ppm}, 2.67 \mathrm{ppm}$, and $5.00 \mathrm{ppm}$ as shown in Table I. The above levels of nitrate and nitrite were chosen on the basis of EPA method $300.0^{7}$. Each sample was run for 3 or more replicates. Standard deviation, relative standard deviation (RSD), and amount found were calculated and are shown in Tables I and II. 
In anion interference studies, dilute nitrite and nitrate standards containing up to $5 \mathrm{mM}$ of chloride, sulfate, carbonate, phosphate, fluoride and oxalate were analyzed under the conditions listed earlier ${ }^{25}$.

The ion chromatography experiments were carried out using a $40 \mathrm{mM}$ sodium hydroxide eluent, containing $1.1 \%$ acetonitrile at a flow rate of $1.2 \mathrm{~mL} /$ minute. The regenerant solution was 50 $\mathrm{mN}$ sulfuric acid at a flow rate of $10 \mathrm{~mL} /$ minute. Dionex Omni Pac PAX-500 column and Dionex Omni Pac PAX-500 guard column were used for the separations. The sample injection loop was $25 \mu \mathrm{L}$. The nitrate and nitrite standards and samples were as described in the RPCE section.

The procedure used for the determination of nitrate in natural water was based on Technicon Industrial Method No. 100-70W/B. Nitrate was reduced to nitrite by copper-cadmium reductor column. The nitrite formed in the reduction was reacted with sulfanilamide under acidic conditions to form a diazo compound, which was then coupled with N-1naphthylethylenediamine dihydrochloride to form a reddish-purple complex that was measured at $520 \mathrm{~nm}$. QA/QC standards $\left(0.10 \mathrm{mg} / \mathrm{L}\right.$ and $\left.0.5 \mathrm{mg} / \mathrm{L} \mathrm{NO}{ }^{-}-\mathrm{N}\right)$ were run to check method performance.

Comparison of RPCE method with IC and cadmium reduction methods was carried out by analyzing real natural water samples. The analysis of natural water samples was carried out in $2.5 \mathrm{mM}$ borate/2.5 mM HMB buffer at $\mathrm{pH} 9.3$, and results were compared with those obtained by IC and cadmium reduction methods. The natural water samples were obtained from the sample 
sites that are regularly monitored for limnological changes by the Washington State Water Research Center. The River Mile (RM) numbers (see Table III) were indicative of the location referenced from the confluence of the Snake River and the Columbia River upstream to the Clearwater River ${ }^{22}$. Top samples were those taken at a depth of 1 meter, mid samples at 17 meters, and bottom samples at 33 meters. A domestic well water sample near Pullman, Washington was also analyzed by the RPCE method, and results were compared with those of the Whitman County Department of Health.

Evaluation of waste generation for running of 100 water samples by the RPCE, IC, and cadmium reduction methods were carried out. The comparison was made on calculated values based on all wastes generated through the bulk flow rates, column preparations, and column conditioning.

\section{RESULTS AND DISCUSSION:}

Detector Sensitivity: The optimal wavelength in the RPCE buffer was found to be $220 \mathrm{~nm}$ for both nitrate and nitrite, the same as that reported in the literature ${ }^{3}$. Hence, the buffer additive, hexamethonium bromide, did not affect the $\lambda_{\max }$ of nitrate and nitrite. Figure 1, however, shows the effect of buffer concentration on the response of nitrate and nitrite at $220 \mathrm{~nm}$. A 25$35 \%$ decrease in the signal of nitrite and nitrate with 10 times increase in buffer concentration was observed. This decrease in signal was due to the increase in background absorption as the concentration of $\mathrm{HMB}$ was increased. Thus, it was advantageous to use a low buffer/modifier concentration for the analysis of very dilute nitrite and nitrate samples. In addition to increased sensitivity, the use of a low buffer/modifier concentration allowed up to $30 \mathrm{kV}$ to be applied 
across the $50 \mu \mathrm{m}$ i.d. by $50 \mathrm{~cm}$ long bare silica column, thereby, decreasing the analysis time. When greater than $20 \mathrm{kV}$ was used for high buffer concentrations, high current was produced which led to electrical breakdowns in the instrument. Moreover, with high voltage and high buffer concentrations, increased Joule heating caused increased noise ${ }^{18,26}$ in the analysis of very dilute samples. The combination of excess noise and background increased the detection limit of nitrate and nitrite in the more concentrated buffer.

Resolution: Figure 2 shows the effect of buffer concentration on separation efficiency and resolution. The resolution, $R_{s}$ of nitrate and nitrite was higher in the $25 \mathrm{mM}$ buffer than in 2.5 $\mathrm{mM}$ buffer to the extent that a $1 \mathrm{mM}$ nitrite and nitrate mixture was not resolved in the low concentration buffer. This effect of enhanced resolution observed using a higher concentration of buffer is well known and can be explained in terms of the resolution equation ${ }^{10}$ :

$$
R_{S_{s}}=\frac{\sqrt{N}[\Delta \mu]}{4\left[\bar{\mu}+\mu_{e o}\right]}=\frac{1}{4} \sqrt{N} \Delta \mu^{\prime}
$$

where $N$ is the number of theoretical plates, $\Delta \mu,\left(\mu_{e 1}-\mu_{e 2}\right)$, is the electrophoretic mobility difference between ion 1 and ion $2 ; \bar{\mu}$ is the average mobility of the ions; $\mu_{\mathrm{eo}}$ is the electroosmotic mobility; and $\Delta \mu^{\prime}$ is the relative mobility ratio, $\quad \frac{\Delta \mu}{\bar{\mu}+\mu_{e o}}$.

Because a negative potential was applied to the injection end of the column, the electroosmotic flow (EOF) was in the opposite direction of the electrophoretic migration of the anions. The EOF was away from the detector therefore neutral molecules were not detected. HMB was 
added to minimize the migration of the electroosmotic flow so that the electrophoretic mobilities of nitrite and nitrate were more than 4 and 6 times greater than the electroosmotic mobility in the low and high concentration buffers respectively. Thus, these anions of interest migrated against the electroosmotic flow to the detector, resulting in slower migration in $2.5 \mathrm{mM}$ buffer than in 25 $\mathrm{mM}$ buffer. Determination of the electroosmotic mobility, $\mu_{\mathrm{e}, \text {, was }}$ carried out with the instrument in normal polarity configuration $(20 \mathrm{kV})$, using $0.6 \mathrm{mM}$ phthalonitrile as a neutral marker in both $2.5 \mathrm{mM}$ borate $/ 2.5 \mathrm{mM} \mathrm{HMB}$ and $25 \mathrm{mM}$ borate $/ 25 \mathrm{mM}$ HMB buffers.

Generally, in situations where there is either a decrease in, or, a reversal of direction of the electroosmotic flow, very high resolution can be achieved (see equation 2). The effects of $\mathrm{pH}$, buffer concentration, ionic strength, injected sample volume, applied voltage, and electroosmotic flow velocity, have been investigated by Jorgenson ${ }^{10}, \mathrm{McNair}^{27}$, Nielen ${ }^{13}$, and Riekkola ${ }^{28}$. Because effective electrophoretic mobility and electroosmosis are inversely proportional to the square root of buffer concentration ${ }^{19}, 29$, low buffer concentration results in higher electrophoretic mobility and electroosmosis.

From equation 2 , the enhanced resolution in high concentration ( $25 \mathrm{mM}$ buffer in this study) was a function of $N$ and $\Delta \mu^{\prime}$. Both $N$ and $\Delta \mu^{\prime}$ increased with buffer concentration. Two factors contributed to the increased $N$ with buffer concentration. First, stacking occurred in the high concentration buffer because the conductivity difference between the buffer and the sample was more pronounced in the $25 \mathrm{mM}$ buffer than in $2.5 \mathrm{mM}$ buffer ${ }^{30}$. Hence, sharper peaks were observed in the $25 \mathrm{mM}$ buffer than in the $2.5 \mathrm{mM}$ buffer (see Figure 2). Another important contribution to the increase in $N$ for $25 \mathrm{mM}$ buffer was that the observed electrophoretic 
mobility, $\mu_{\mathrm{obs}}\left(\mu_{\mathrm{obs}}=\mu_{\mathrm{e}}+\mu_{\mathrm{eo}}\right.$ ), was higher in $25 \mathrm{mM}$ buffer than in $2.5 \mathrm{mM}$ buffer (see Figure 2). Second, $N$, when band spreading is under diffusion control and minimal dispersion due to Joule heating, has been expressed ${ }^{28}$ as

$$
N=\frac{\left(\mu_{e}+\mu_{e o}\right) V}{2 D}
$$

where $\mathrm{D}$ is the molecular diffusion coefficient of the ion. Because $\mu_{\mathrm{eo}}$ was in the opposite direction of $\mu_{\mathrm{e}}$ for anions and was lower in $25 \mathrm{mM}$ buffer than in $2.5 \mathrm{mM}$ buffer, $\mu_{\mathrm{obs}}$ was higher in the $25 \mathrm{mM}$ buffer. Remember that the $25 \mathrm{mM}$ buffer contains a higher concentration of the electroosmotic flow modifier, hexamethonium bromide. This increase in $\mu_{\mathrm{obs}}$ at higher buffer concentrations also caused an increase in $\Delta \mu^{\prime}$. The relative mobility ratio for $25 \mathrm{mM}$ buffer was about twice that of $2.5 \mathrm{mM}$ buffer.

Detection Limit: On-column preconcentration in CZE, caused by the conductivity mismatch ${ }^{11}$, 13, 31 between the sample zone and the buffer zone, is known as stacking and can not only increase separation efficiency as discussed in the previous section, but also can be used to decrease the detection limit of analysis. For a dilute sample, the conductivity of the sample zone is lower than that of the buffer, resulting in a higher resistivity in the sample zone. The electric field across the sample zone, which is directly proportional to resistivity, is therefore higher than the electric field in the background buffer. The resultant effect of the higher electric field in the sample zone is that ions in the trailing edge of the sample zone migrate faster towards the higher concentration region than the ions in the leading sample zone, which slow down as they reach the 
buffer region. The ions, therefore, concentrate (or stack) at the concentration boundary between the leading edge of the sample zone and the buffer zone.

Figure 3 is a plot of signal-to-noise ratio versus time of gravity injection in a $2.5 \mathrm{mM}$ borate/HMB buffer. There was a steep increase in peak height due to the stacking phenomenon described above as the injection time was increased from 20 to 200 seconds. No further large gain in signal-to-noise ratio was observed at injection times above 200 seconds, presumably due to the effects of band broadening from the large sample volume. The saturation point in Figure 3 is called the threshold injection time, that injection time at which large volume dispersion effects became noticeable. The conductivity difference between the sample zone after stacking and the buffer zone decreases with increasing injection times. Under conditions of matched sample and electrolyte conductivity, the migration times of the leading tailing edges of the sample zone balance and a Gaussian distribution of the analyte ions in the concentration zone occurs ${ }^{30-34}$. The change in peak height per unit time of injection was greater at shorter injection times because of low sample volume (minimum peak broadening). In addition, the conductivity of the sample zone after stacking was lower than the conductivity of the buffer. At prolonged injection times, the signal-to-noise per unit time of injection leveled off because as the injected volume increased, peak broadening due to large injection volume became significant and even led to a decrease in peak height.

A comparison between pressure and gravity injection methods showed that gravity injection gave better stacking effects than the pressure injection method. The detection limit based on gravity injection under stacking conditions is shown in Figure 4. This figure shows that for a very dilute 
sample, detection limits $(\mathrm{s} / \mathrm{n}=3)$ of $3.8 \pm 0.4 \mathrm{ppb} \mathrm{N}$-nitrite, and $2.0 \pm 0.2 \mathrm{ppb} \mathrm{N}$ - nitrate (276 and $145 \mathrm{nM}$ ), were obtained for 180 second injection times. Detection limits of $1.18 \pm 0.03 \mathrm{ppb} \mathrm{N}$ $(84 \pm 2 \mathrm{n} M)$ nitrite and $0.68 \pm 0.07 \mathrm{ppb} \mathrm{N}-(48 \pm 5 \mathrm{n} M)$ nitrate were obtained for injection time of 1000 seconds. Generally, 60 second gravity injection time is recommended in the analysis of natural water samples containing low ppm levels of nitrate and nitrite.

Interferences: Anion interference studies showed that because this RPCE method was based on direct UV detection, it had the advantage of reduced interference from non-absorbing species like sulfate, chloride, carbonate, fluoride, and phosphate anions. However, because the electroosmotic flow modifier, hexamethonium bromide, used in this method absorbed in the same wavelength region as nitrate and nitrite, non-absorbing anions were observed as negative peaks in the electropherogram. In Figure 5, the migration times of the potentially interfering anions were found to be different from those of nitrate and nitrite. Thus, these ions do not interfere with the analysis. The addition of anions to the sample produced an indirect interference by increasing the sample ionic strength, which decreased the resolution of nitrite and nitrate. This problem was solved by adding sodium bromide to increase the ionic strength of the buffer. The effects buffer/sample ionic strength ratio on efficiency and resolution was recently examined. It was found that separation efficiency and resolution in RPCE can be approximated to a function of the square root buffer/sample ionic strength ${ }^{25}$. A primary advantage of RPCE over standard methods for nitrate and nitrate is that the absorbing neutral compounds and cations migrate away from the detector and do not interfere with response. 
Analysis: Table I is the summary of the reproducibility and accuracy studies for spiked samples of nitrate and nitrite. The results tabulated were expressed in terms of nitrite as nitrogen $\left(\mathrm{NO}_{2}^{-}{ }^{-}\right.$ N) and nitrate as nitrogen $\left(\mathrm{NO}_{3}{ }^{-}-\mathrm{N}\right)$. The percent recovery of nitrite and nitrate in drinking water and laboratory tap water were comparable to the percent recovery in reagent water. The precision for 3 replicate runs was $3.6 \%$ relative standard deviation (RSD) for nitrate, and $6.5 \%$ for nitrite. A slight increase in RSD was observed for lower concentration standards $(<2.0$ ppm), but the RSD was always less than $10 \%$. These results are very comparable with those obtained for IC in this laboratory (Table II), and with the published results in the IC based Standard Methods ${ }^{6}$ and EPA Method $300.0^{7}$.

Table III is the summary of results obtained for analysis of natural water samples. The RPCE results compared closely with those obtained by FIA and IC. Except for a few values that were exactly the same, it was observed that RPCE results were consistently higher than those obtained using the cadmium reduction. For this reason, a statistical Student $t$-test analysis at $95 \%$ confidence levels for each sample mean values was performed on the result, between RPCE and cadmium reduction. This statistical analysis showed that the two means were not significantly different, except for the AB. CONF. samples. Although the reason for the observed small difference between the RPCE and the cadmium reduction for these samples was not known. This discrepancy may have been due to interferences commonly associated with the cadmium reduction method. Note that a 5\% standard deviation was applied on all the cadmium reduction data, based on the established precision of a fully optimized method ( $R$. Ramian, personal communication). The standard deviations for RPCE and IC were based on 3 replicate measurements. 
Figure 6 is the electropherogram of the analysis of another natural water - a domestic well water sample. This well was monitored by the Whitman County Department of Health because of its unusually high level of nitrate. Figure 6 is a 1:5 dilution of the sample and represents $2.06 \pm$ $0.09 \mathrm{ppm} \mathrm{NO}_{3}{ }^{-}-\mathrm{N}$. The well water contained $10.1 \mathrm{ppm}$ nitrate. This result compared well with that from the Health Department.

Waste generation was compared for 100 water samples among RPCE, Cd-FIA, and methods. From calculated values, a 3 minute RPCE run time generated about $100 \mathrm{~mL}$ waste. For Cd-FIA, in addition to about $120 \mathrm{~mL}$ of waste generated during the preparation of $\mathrm{Cd}$ column, the total volume of waste generated during a 3 minutes analysis time was about $740 \mathrm{~mL}$. For IC, the waste generated from the bulk flow including the regenerant at about $11.2 \mathrm{~mL} / \mathrm{min}$., was about 4.5 L. Therefore, RPCE gave analysis waste reduction by greater than one order of magnitude when compared to Cd- FLA, and by more than two orders of magnitude when compared to IC.

\section{CONCLUSIONS:}

The rapid reverse polarity capillary zone electrophoresis analysis of nitrite and nitrate was used successfully in the presence of anions that would normally interfere in spectrophotometric, cadmium reduction and ion chromatographic methods. This simple method with high sample throughput was used for the analysis of river and groundwater samples. Resolution of nitrate from nitrite was better in high buffer concentration than in low buffer concentration because of both a higher separation efficiency and greater relative mobility difference in the higher buffer 
concentration. Increasing the buffer ionic strength (without increasing the buffer concentration) was used to improve the resolution of nitrite and nitrate in samples that have high sample/ buffer ionic strength ratio. This principle will be useful in analyzing samples of high salt contents like seawater. Very low concentration samples can be analyzed using this method because oncolumn sample preconcentration occurred by stacking. Detection limits of $3.8 \pm 0.4 \mathrm{ppb} \mathrm{N}$ nitrite, and $2.0 \pm 0.2 \mathrm{ppb} \mathrm{N}$ - nitrate (271 and $143 \mathrm{nM}$ ) were obtained for a gravity injection time of 3 minutes, and sub ppb limits were measured for prolonged injection times. The method also reduced laboratory waste by a factor of more than one order of magnitude when compared to $\mathrm{Cd}-$ FIA and greater than two orders of magnitude when compared to IC method.

\section{ACKNOWLEDGMENTS:}

We are indebted to Dr. Steve T. J. Juul of the Water Research Center, Washington State University, Pullman, Washington, for providing the natural water samples and for allowing us use their Cd-FIA data. We thank also Mr. Richard Ramian, (Environmental Science/Regional Planning Program, Washington State University, Pullman, WA) who performed the cadmium reduction analyses. We also appreciate the kindness of Drs. John and Ardith Pierce for providing the well water sample. This work was supported in part by a grant from Westinghouse Hanford Company, Richland, WA. 


\section{REFERENCES:}

1. Cawse, P.A. Analyst. 1967, 92, 311.

2. Wetters, J.H.; Uglum, K.H. Anal. Chem., 1970, 42, 335.

3. Standard Methods for the Examination of Water and Wastewater; Greenberg, A.E.;

Clesceri, L.S.; Eaton, M.A., Eds.; American Public Health Association, 1992; 18th ed.; p $4-85$,

4. Johnson, K. S.; Petty, R. L. Limnol. Oceanogr. 1983, 28, 1260.

5. Oudot, C.; Montel, Y. Marine Chemistry. 1988, 24, 239.

6. Standard Methods for the Examination of Water and Wastewater; Greenberg, A.E.;

Clesceri, L.S.; Eaton, M.A., Eds.; American Public Health Association, 1992; 18th ed.; p 4-1.

7. EPA Method 300.0 Determination of Inorganic Anions by Ion Chromatography; United States Environmental Protection Agency, Cincinnati, OH., 1993; p 300.0.

8. Takeda, K.; Fujiwara, K. Anal. Chimica Acta. 1993, 276, 25.

9. Koch, W.F. Anal. Chem. 1979, 51, 1571.

10. Jorgenson, J.W.; Lukacs, K. D. Anal. Chem. 1981, 53, 1298.

11. Camilleri, P. Capillary Electrophoresis. CRC Press; Boca Raton, Fl., 1993; p 26.

12. Amran, M.B.; Lakkis, M.D.; Lagarde, F.; Leroy, M.J.F.; Lopez-Sanchez, J.F.; Rauret, G. Fresenius J. Anal. Chem. 1992, 345, 420.

13. Burgi, D.S.; Chien, R-L. Anal. Chem. 1992, 202, 306.

14. Nielen, M.W.F. J. Chromatogr. 1991, 546, 173.

15. Romano, J.; Jandik, P.; Jones, R. W.; Jackson, P. E. J. Chromatogr. 1991, 546, 411. 
16. Jones, W.R.; Jandik, P. J. Chromatogr. 1991, 546, 445.

17. Jandik, P.; Jones, W. R. J. Chromatogr. 1991, 546, 431.

18. Li, K.; Li, S.F.Y. J. Liq. Chromatogr. 1994, 17, 3889.

19. Kelly, L.; Nelson, R. J. J. Liq. Chromatogr. 1993, 16, 2103.

20. Shamsi, S.; Danielson, N. D. Anal. Chem. 1994, 66, 3757.

21. Avdalovic, N.; Pohl, C. A.; Rocklin, R. D.; Stillian, J. R. Anal. Chem. 1993, 65, 1470.

22. Funk, W.H.; Falter, C .; Lingg, Al.J. "Limnology of an Impoundment Series in the Lower

Snake River."; final report submitted to Walla Walla District U.S Corps of Engineers:

Walla Walla, WA, 1985.

23. Haung, X.; Gordon, M .; Zare, R Anal. Chem. 1989, 60, 375.

24. Dionex Corporation Doc. 034196-02 11/90 Sunnyvale, CA: 1990; p 1201.

25. Okemgbo, A.A., Ph.D. Dissertation. Washington State University. May 1997. Chapter 2.

26. Chien, R-L.; Burgi, D.S. J. Chromatogr. 1991, 559, 153.

27. Rasmussen, H.T.; McNair, H.M. J. Chromatogr. 1990, 516, 223.

28. Jumppenen, J.H.; Riekkola, M-L.; Haario, H. J. Microcol. Sep. 1994, 6, 595.

29. Atamna, I.Z.; Issaq, H. J.; Muschik, G. M.; Janini, G. M. J. Chromatogr. 1991, 588, 315.

30. Vinther, A.; Sфeberg, H. J. Chromatogr. 1991, 559, 27.

31. Chien, R-L.; Burgi, D.S. J. Chromatogr. 1991, 546, 141.

32. Burgi, D.S.; Chien, R-L. Anal. Chem. 1991, 63, 2042.

33. Vinther, A. J. Chromatogr. 1991, 559, 3.

34. Friedl, W.; Reijenga, J.C.; Kenndler, E. J. Chromatogr. A. 1995, 709, 163. 
Table I

PRECISION AND ACCURACY OF RCPE METHOD FOR NITRITE AND NITRATE IN WATER SAMPLES

\begin{tabular}{ccccc}
\hline & \multicolumn{2}{c}{ NITRITE-N } & \multicolumn{2}{c}{ NITRATE-N } \\
\hline Sample & Amount Added (ppm) & Amount Found (ppm) & Amount Added (ppm) & Amount Found (ppm) \\
Reagent Water & 1.00 & $0.98 \pm 0.09$ & 1.00 & $1.01 \pm 0.09$ \\
Drinking Water & 5.00 & $4.99 \pm 0.16$ & 5.00 & $4.95 \pm 0.17$ \\
Lab Tap Water & 2.67 & $2.66 \pm 0.01$ & 1.68 & $1.60 \pm 0.08$ \\
\hline
\end{tabular}


Table II

PRECISION DATA OF IC METHOD FOR NITRITE AND NITRATE IN WATER SAMPLES

\begin{tabular}{ccccc}
\hline & \multicolumn{3}{c}{ NITRITE-N } & \multicolumn{2}{c}{ NITRATE-N } \\
\hline Sample & Amount Added (ppm) & Amount Found (ppm) & Amount Added (ppm) & Amount Found (ppm) \\
Reagent Water & 5.00 & $4.72 \pm 0.24$ & 5.00 & $4.99 \pm 0.11$ \\
Reagent Water & 2.00 & $1.87 \pm 0.18$ & 2.00 & $2.07 \pm 0.07$ \\
\hline
\end{tabular}


Table III

COMPARISON OF RESULTS OF NITRATE ANALYSIS OF NATURAL WATER BY RPCE, IC AND Cd REDUCTION METHODS

\begin{tabular}{cccc}
\hline SAMPLE & Cd REDUCTION & RPCE & IC \\
& $\mathrm{NO}_{3}-\mathrm{N}(\mathbf{p p m})$ & $\mathrm{NO}_{3}-\mathrm{N}(\mathbf{p p m})$ & $\mathrm{NO}_{3}-\mathrm{N}(\mathbf{p p m})$ \\
RM118TOP & $0.32 \pm 0.02$ & $0.33 \pm 0.02$ & $0.33 \pm 0.04$ \\
RM118MID & $0.29 \pm 0.01$ & $0.32 \pm 0.03$ & $0.45 \pm 0.11$ \\
RM118BOT & $0.29 \pm 0.01$ & $0.34 \pm 0.09$ & $0.36 \pm 0.03$ \\
RM108TOP & $0.40 \pm 0.02$ & $0.40 \pm 0.04$ & \\
RM108MID & $0.37 \pm 0.02$ & $0.42 \pm 0.07$ & \\
RM129TOP & $0.29 \pm 0.02$ & $0.39 \pm 0.08$ & \\
RM129MD & $0.32 \pm 0.02$ & $0.42 \pm 0.06$ & \\
RM129BOT & $0.31 \pm 0.02$ & $0.40 \pm 0.04$ & \\
AB. CONF. TOP & $0.43 \pm 0.02$ & $0.51 \pm 0.04$ & \\
AB. CONF.BOT & $0.46 \pm 0.02$ & $0.51 \pm 0.08$ & \\
CLEARWATER & $0.13 \pm 0.01$ & $0.13 \pm 0.02$ & \\
\hline
\end{tabular}




\section{FIGURE CAPTIONS}

Figure 1. Effects of buffer concentration on the response of nitrite and nitrate.

Electrophoretic buffer: equimolar $2.5 \mathrm{mM}, \quad 5.0 \mathrm{mM}, 10.0 \mathrm{mM}$, and $25.0 \mathrm{mM}$ Borate/Hexamethonium bromide, respectively, at $\mathrm{pH}: 9.3$, wavelength: $220 \mathrm{~nm}$. Column: $50 \mathrm{~cm}$ long x $50 \mu \mathrm{m}$ i.d. bare fused silica. Applied voltage: $-20 \mathrm{kV}$, negative polarity. Gravity injection time: 60 s.

Figure 2. Effects of buffer concentration on separation efficiency of nitrate and nitrite. Resolution and mobility were reduced at low buffer concentrations. The electropherogram of 1.3 $\mathrm{mM}$ nitrite and $1.1 \mathrm{mM}$ nitrate mixture, using $-20 \mathrm{kV}$ in a buffer concentration of: (a) $2.5 \mathrm{mM}$ borate/HMB buffer,. (b) $25 \mathrm{mM}$ borate/HMB buffer

Figure 3. Signal-to-noise ratio as a function of gravity injection, illustrating the concentration benefit of on-column sample stacking. Sample concentrations were (a) $182 \mathrm{ppb}-\mathrm{N}$ nitrite, (b) $154 \mathrm{ppb}-\mathrm{N}$ nitrate, (c) $18 \mathrm{ppb}-\mathrm{N}$ nitrite, and (d) $15 \mathrm{ppb}-\mathrm{N}$ nitrate standards. Electrophoretic buffer: $2.5 \mathrm{mM}$ borate $2.5 \mathrm{mM}$ hexamethonium bromide, $\mathrm{pH}$ : 9.3 , wavelength: $220 \mathrm{~nm}$. Column: $50 \mathrm{~cm}$ long x $50 \mu \mathrm{m}$ i.d. bare fused silica. Applied voltage: $-20 \mathrm{kV}$. Gravity injection time: $30-1000$ s.

Figure 4. Detection Limit dependence on the gravity injection time. A detection limit of $1.18 \pm 0.03 \mathrm{ppb}-\mathrm{N}(84 \pm 2 \mathrm{nM})$ nitrite and $0.68 \pm 0.07 \mathrm{ppb}-\mathrm{N}(48 \pm 5 \mathrm{nM})$ nitrate was achieved for injection time of 1000 seconds. For 180 seconds injection time, detection limits of $3.8 \pm 0.4$ 
ppb N-nitrite, and 2.0 $\pm 0.2 \mathrm{ppb} \mathrm{N}$ - nitrate (276- and $145 \mathrm{nM}$ ), were obtained. Conditions as in Figure 3.

Figure 5. Anion interferences study. The addition of sodium bromide was adjusted to a concentration of $37.5 \mathrm{mM}$ sodium bromide in the $2.5 \mathrm{mM}$ borate/ $2.5 \mathrm{mM} \mathrm{HMB}$ buffer, for the separation of a sample containing $1 \mathrm{mM}$ each of chloride, sulfate, oxalate, fluoride and phosphate, and $0.29 \mathrm{mM}$ each of nitrite and nitrate. Applied voltage was $-22 \mathrm{kV}$, across a $50 \mathrm{~cm}$ long $\mathrm{x} 50 \mu \mathrm{m}$ i.d. bare fused silica column. Gravity injection was $100 \mathrm{~mm}$ head height for 60 seconds.

Figure 6. Example electropherogram of a 1/5 dilution of a domestic well water sample containing $2.06 \mathrm{ppm} \mathrm{NO}_{3}^{-}-\mathrm{N}$. Electrophoretic conditions were as in Figure 1, with - $30 \mathrm{kV}$ applied voltage. 

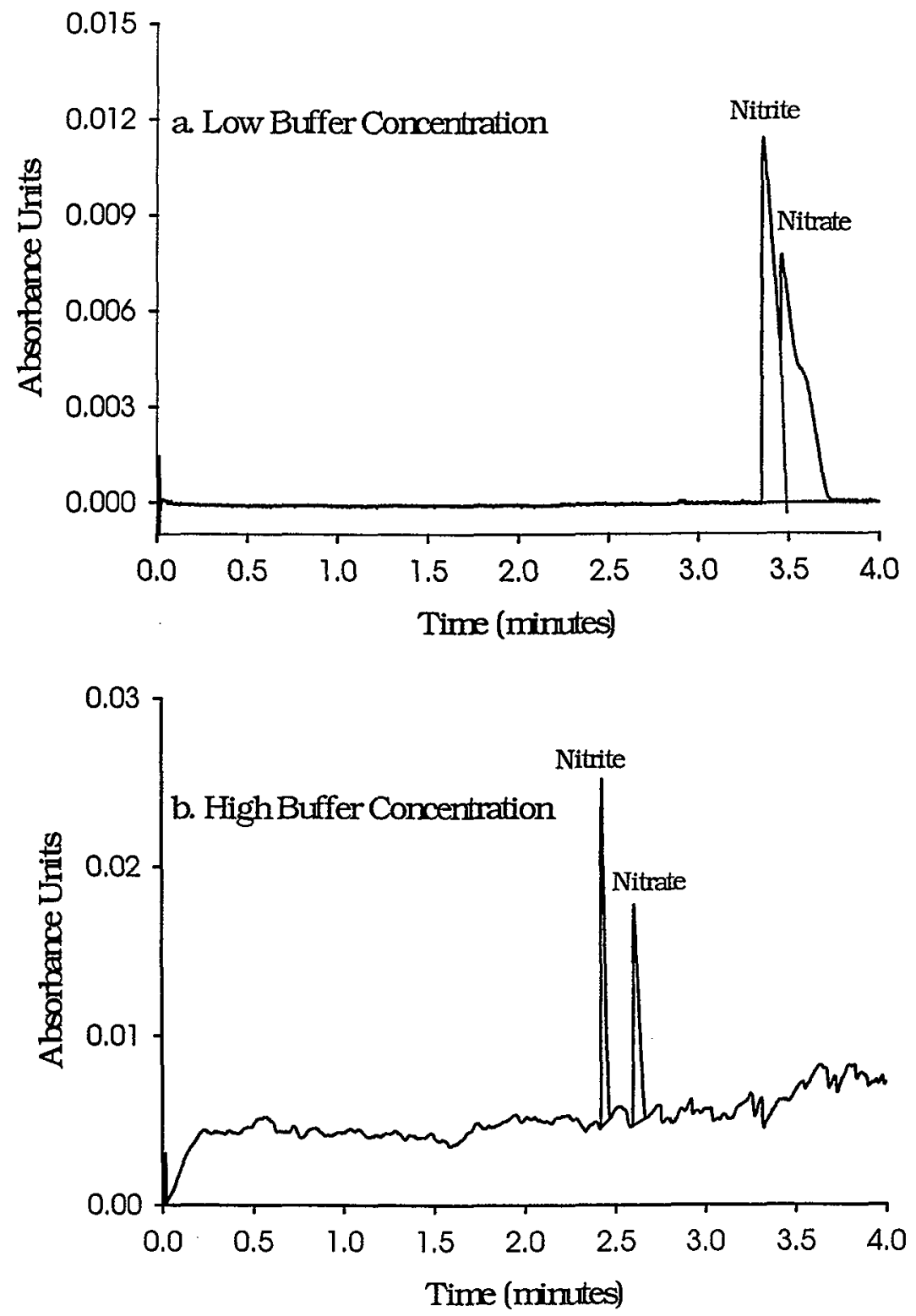

Figure 2. Okemgbo et al. Reverse Polarity Capillary Zone Electrophoretic.... 


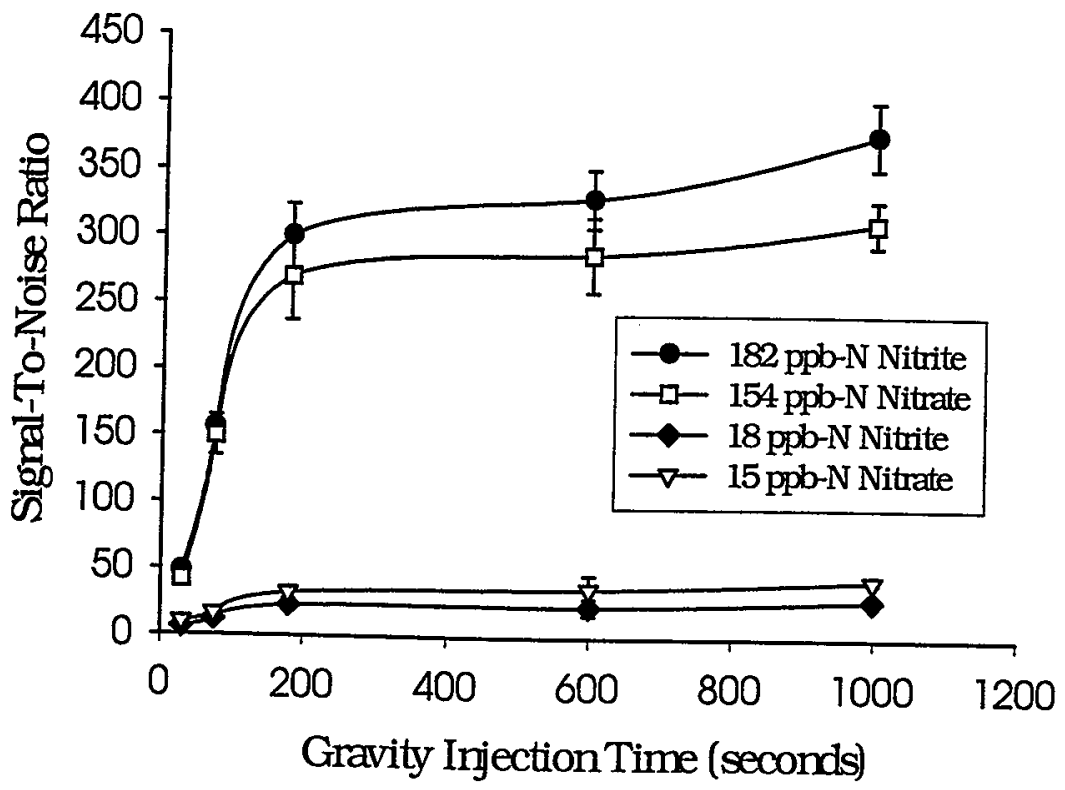

Figure 3. Okemgbo et al. Reverse Polarity Capillary Zone Electrophoretic.... 


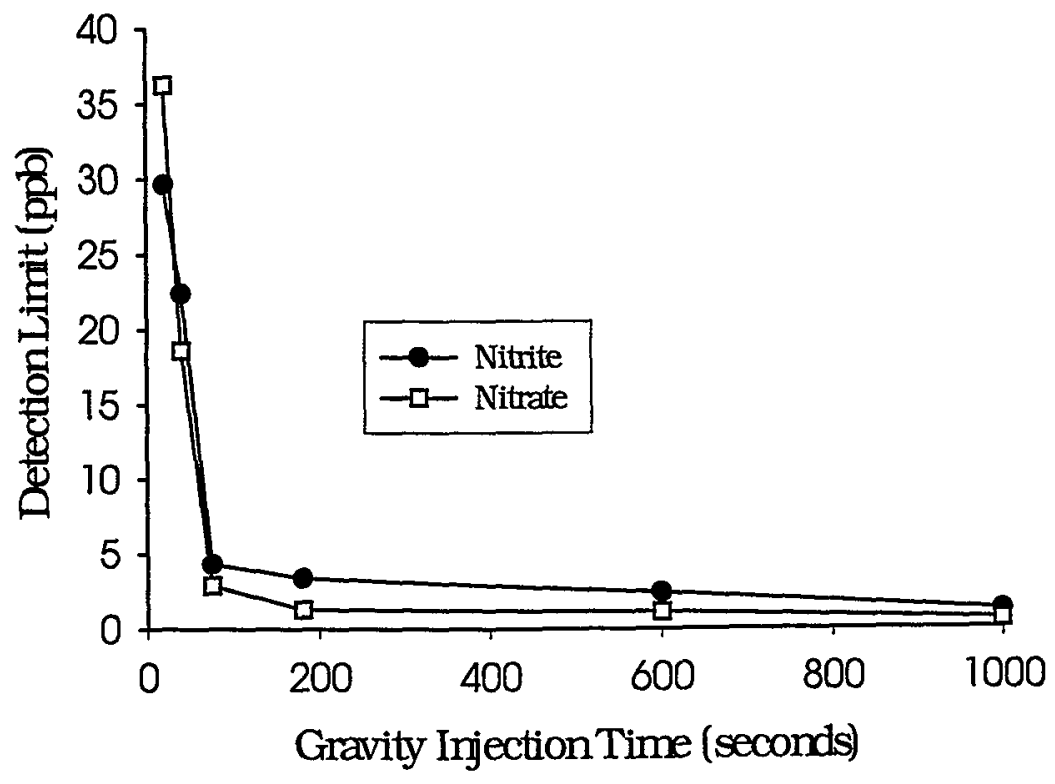

Figure 4 Okemgbo et al. Reverse Polarity Capillary Zone Electrophoretic.... 


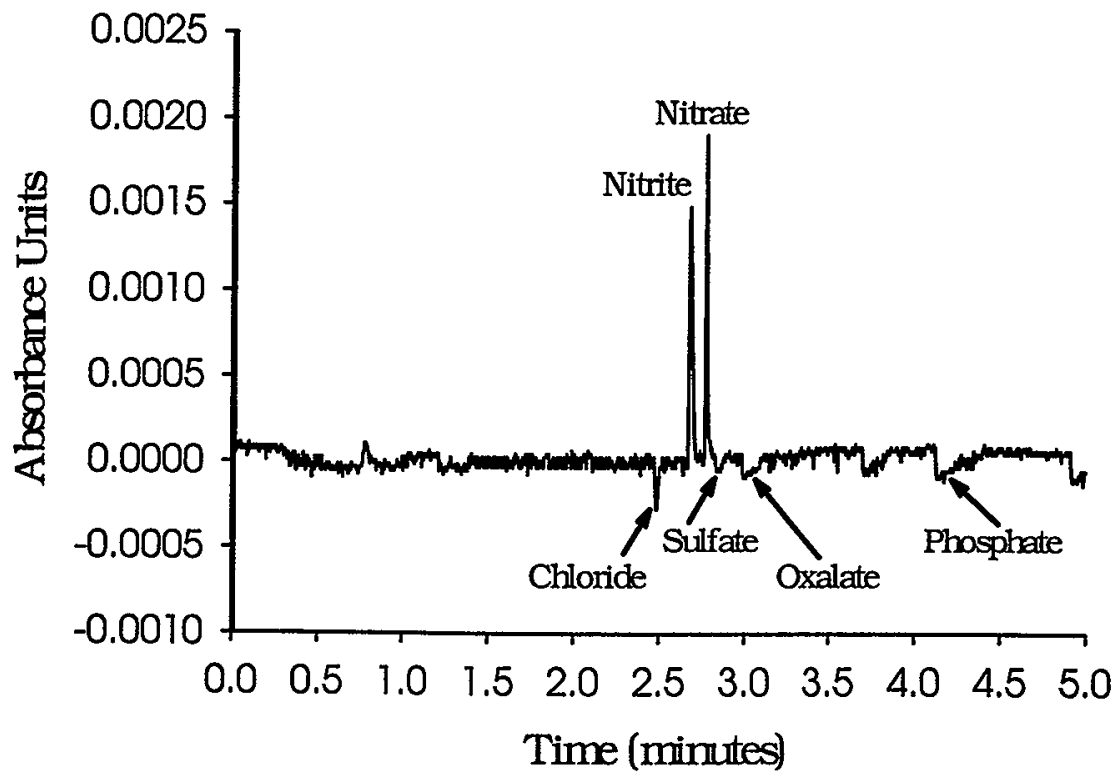

Figure 5. Okemgbo et al. Reverse Polarity Capillary Zone Electrophoretic.... 


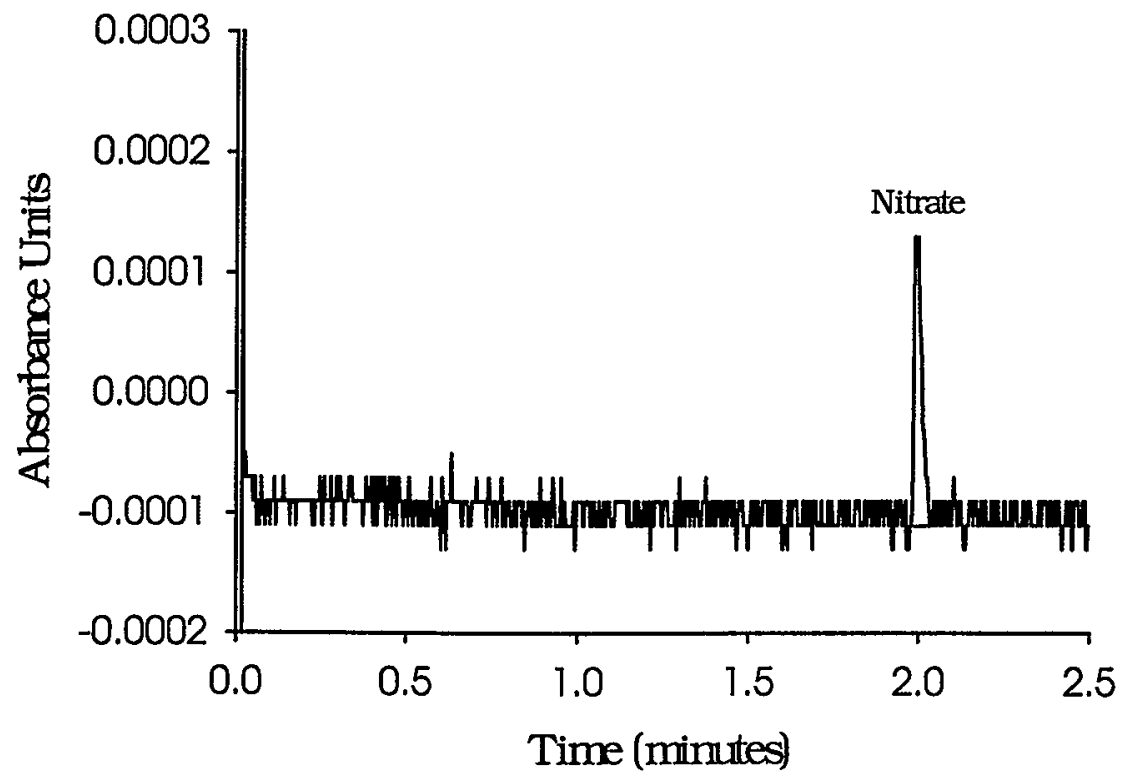

Figure 6. Okemgbo et al. Reverse Polarity Capillary Zone Electrophoretic.... 